\title{
UJI ADAPTASI KLON KARET HARAPAN IRR SERI 200 PADA MASA TANAMAN BELUM MENGHASILKAN DI DAERAH BERIKLIM BASAH, KEBUN AEK TARUM-KABUPATEN ASAHAN
}

\author{
The Adaptation Test of IRR 200 Series Rubber Promising Clones on Immature Period \\ in Wet Climate Area, Aek Tarum Plantation-asahan District
}

\author{
SAYURANDI $^{1)}$, Irwan SUHENDRY ${ }^{2)}$ dan Sekar WOELAN ${ }^{21}$ \\ ${ }^{11}$ Balai Penelitian Sungei Putih, Pusat Penelitian Karet \\ P.O. Box 1415 Medan 20001 Sumatera Utara \\ e-mail : sayurandi_sp@yahoo.com \\ ${ }^{21}$ Pusat Penelitian Karet \\ Jalan Salak Nomor 1 Bogor 16151 \\ e-mail : irwansuhendry@gmail.com; sekaryudi@yahoo.com
}

Diterima: 18 November 2014/ Direvisi: 20 Desember 2014 / Disetujui : 6 Mei 2015

\begin{abstract}
In rubber plant, the condition of rainfall and the number of raindays condition could be one of the limiting factors of optimum rubber plant growth. In general, the rubber plant can grow and produce optimum with rainfall conditions ranging from $1800-2500 \mathrm{~mm} / \mathrm{yr}$ and number of raindays ranges from $115-150$ days/yr. Thus, the selection of superior clones which can adapt to environmental stress condition is very important. The objective of this research was to evaluate the performance of superior promising clones of IRR 200 series in wet climate area. Adaptation test of IRR 200 series clones and comparing clone PB 260 were conducted at Aek Tarum Estate, Asahan District in 2010. The rainfall average for eight years in this research were $2899 \mathrm{~mm} / \mathrm{yr}$ and avarege raindays was 186 days/yr. The number of rainfall and raindays in this research were categorized as high, so this condition influenced growth and rubber productivity less than optimum. The observation on girth growth character was done at age 1 - 4 years. Barkthickness and bark anatomy characters were observed at age 4 years. The attack intensity of Oidium Colletotrichum, and Corynespora leaffall diseases observed at 3 and 4 years. The research results showed that IRR 205, IRR 210, IRR 215, IRR 219, and IRR 220 clones had growth vigorously. IRR 205, IRR 201, and IRR 215 clones had highest barkthickness, and IRR 215 and 219 clones had good bark anatomy. All clones of IRR 200 series classified from moderatly resistant to resistant to Colletotrichum, Oidium, and Corynespora leaffall diseases.
\end{abstract}

Keywords: Hevea brasiliensis, IRR 200 series, adaptation trial, wet climate, growth, secondary characters

\section{Abstrak}

Pada tanaman karet, kondisi curah hujan dan hari hujan bisa merupakan salah satu faktor pembatas untuk pertumbuhan tanaman secara optimal. Pada umumnya tanaman karet dapat tumbuh dan berproduksi optimal pada kondisi curah hujan berkisar $1800-2500 \mathrm{~mm} /$ th dan jumlah hari hujan berkisar 115 - 150 hari/th. Dengan demikian, seleksi klon karet unggul yang dapat beradaptasi dengan baik pada kondisi cekaman lingkungan tertentu seperti curah hujan tinggi sangat penting dilakukan. Tujuan penelitian ini adalah untuk mengevaluasi keragaan klon karet unggul harapan IRR seri 200 pada wilayah beriklim cukup basah. Pengujian adaptasi klon unggul harapan IRR seri 200 dan klon pembanding PB 260 dibangun di Kebun Aek Tarum, Kabupaten Asahan pada tahun 2010. Rata-rata curah hujan selama delapan tahun di lokasi penelitian ini sebesar $2899 \mathrm{~mm} /$ th dengan jumlah hari hujan sebanyak 186 hari/th. Jumlah curah hujan dan hari hujan di lokasi penelitian ini tergolong tinggi, sehingga kurang optimal untuk pertumbuhan dan produktivitas tanaman karet. Pengamatan terhadap karakter pertumbuhan lilit batang dilakukan pada umur 1 - 4 tahun. Karakter tebal kulit dan anatomi kulit diamati pada umur 4 tahun. Intensitas serangan penyakit gugur daun Colletotrichum, Oidium, dan Corynespora diamati pada umur 3 dan 4 tahun. Hasil penelitian menunjukkan bahwa klon IRR 205, IRR 210, IRR 215, IRR 219, dan IRR 220 memiliki pertumbuhan jagur. Klon IRR 205, IRR 210, dan 215 memiliki ukuran tebal kulit paling tinggi, sedangkan klon IRR 215 dan IRR 219 memiliki karakter anatomi yang cukup baik. Semua klon IRR seri 200 yang diuji tergolong moderat resisten sampai dengan resisten 
terhadap penyakit gugur daun Colletotrichum, Oidium, dan Corynespora.

Kata kunci: Hevea brasiliensis, IRR seri 200, uji a d a ptasi, iklim basah, pertumbuhan, karakter sekunder

\section{PENDAHULUAN}

Kegiatan pemuliaan dan seleksi tanaman karet di Indonesia telah berjalan selama empat generasi (G-4) yang diawali sejak tahun 1910 (Aidi-Daslin et al., 2009). Dari aktifitas pemuliaan dan seleksi tersebut telah diperoleh berbagai klon karet unggul dengan potensi produktivitas karet mencapai lima kali lebih tinggi dibandingkan dengan tanaman karet asal bibit semaian (seedling) (Woelan et al., 2008). Klon karet anjuran skala komersial seperti PB 260, PB 330, PB 340, RRIC 100, BPM 24, IRR 112 dan IRR 118 telah banyak dikembangkan di berbagai perkebunan besar dan perkebunan rakyat dengan produktivitas aktualnya dapat mencapai 2000-2500 kg/ha (AidiDaslin et al., 2009). Disamping klon-klon tersebut, masih terdapat sejumlah klon karet unggul harapan seperti klon IRR seri 200 yang masih dalam tahap pengujian lanjutan (Aidi-Daslin et al., 2011; Sayurandi dan Aidi-Daslin, 2012).

Penggunaan klon-klon karet unggul di Indonesia pada saat ini cukup signifikan, namun pencapaian produktivitas aktualnya masih beragam. Perbedaan produktivitas klon tersebut menurut sejumlah peneliti diantaranya karena adanya perbedaan respons klon pada keadaan agroekosistem yang berbeda (Mydin et al., 2012; AidiDaslin, 2011). Menurut Vinod et al. (2010) bahwa setiap klon memiliki respon terhadap lingkungan yang berbeda. Aidi-Daslin et al. (2007) menyatakan bahwa setiap klon akan membutuhkan kondisi lingkungan yang sesuai untuk pertumbuhannya guna mewujudkan tingkat produktivitas karet yang optimal. Dari beberapa hasil penelitian sebelumnya menunjukkan bahwa beberapa klon karet dapat beradaptasi pada berbagai daerah dengan agroekosistem yang luas, tetapi ada juga klon yang hanya dapat tumbuh baik pada lingkungan yang spesifik (Setiono dan Hadi, 2006; Aidi-Daslin dan Sayurandi, 2006).
Perkebunan karet Indonesia sebagian besar terletak di pulau Sumatera, Jawa dan Kalimantan dengan jumlah curah hujan berkisar 1500 - $4000 \mathrm{~mm} /$ th dan jumlah bulan kering berkisar 0 - 4 bulan per tahun (Thomas et al., 2009). Menurut Hadi et al. (2007), produktivitas tanaman karet selain dipengaruhi oleh faktor genetik juga dipengaruhi oleh faktor lingkungan seperti curah hujan, baik jumlah maupun frekuensinya. Selain faktor tersebut, ketinggian tempat, topografi, dan sifat fisik tanah juga dapat mempengaruhi pertumbuhan dan produktivitas tanaman (Sugiyanto et al., 1998).

Penurunan produksi karet akibat kesalahan penanaman klon yang tidak sesuai pada daerah beriklim basah (curah hujan $>3000 \mathrm{~mm} /$ th tanpa bulan kering) dapat mencapai 40\%. Menurut Suhendry (2001), terdapat perbedaan laju penurunan populasi tanaman dan keterlambatan matang sadap sejumlah klon yang ditanam pada daerah dengan agroklimat basah dibandingkan pada daerah dengan curah hujan normal. Pemilihan klon yang sesuai untuk penanaman pada suatu lingkungan (agroekosistem) perlu menjadi pertimbangan agar suatu klon unggul dapat memperagakan keunggulannya secara optimal. Dengan demikian diperlukan alternatif pilihan jenis klon unggul yang dapat dikembangkan pada lingkungan spesifik.

Informasi ketahanan klon IRR seri 200 terhadap penyakit gugur daun penting diketahui sejak awal, sebab tanaman yang rentan terhadap penyakit gugur daun akan menyebabkan terhambatnya pertumbuhan dan berpengaruh terhadap lamanya matang sadap (Basuki et al., 1990; Thomanee et al., 1992; Hadi, 2005). Penyakit gugur daun yang masih dianggap paling berbahaya pada tanaman karet pada saat ini adalah penyakit gugur daun Colletotrichum, Oidium, dan Corynespora. Pengamatan terhadap penyakit gugur daun tersebut diharapkan dapat memperoleh informasi klon IRR seri 200 yang memiliki ketahanan genetik kuat.

Tulisan ini melaporkan hasil evaluasi kinerja klon karet unggul harapan IRR seri 200 pada tahap pengujian adaptasi selama masa tanaman belum menghasilkan (TBM) di lokasi pengujian Kebun Aek Tarum, Kabupaten Asahan. 


\section{BAHAN DAN METODE}

Plot pengujian klon IRR seri 200 dibangun di Kebun Aek Tarum, Kabupaten Asahan, Provinsi Sumatera Utara pada tahun 2010. Rancangan yang digunakan dalam penelitian ini adalah rancangan Augmented dalam RAK. Sebanyak tujuh klon IRR seri 200 yaitu IRR 205, IRR 208, IRR 210, IRR 215, IRR 218, IRR 219, IRR 220 dan klon pembanding PB 260 diuji pada penelitian ini. Masing-masing klon ditanam sebanyak 250 pohon dengan jarak tanam $5 \mathrm{x}$ $4 \mathrm{~m}$. Jumlah sampel tanaman yang diamati pada penelitian ini sebanyak 20 pohon per klon. Deskripsi pengujian adaptasi klon karet IRR seri 200 di Kebun Aek Tarum disajikan pada Tabel 1 .

Parameter yang diamati pada penelitian ini yaitu pertumbuhan lilit batang TBM yang diukur dari TBM-1 sampai dengan TBM-4, tebal kulit dan anatomi kulit jumlah cincin pembuluh lateks dan diameter sel pembuluh lateks) diamati pada umur 4 tahun, serta intensitas serangan penyakit gugur daun diamati pada umur 3 dan 4 tahun. Pengamatan setiap parameter dilakukan sebagai berikut:

Tabel 1. Deskripsi pengujian adaptasi klon karet IRR seri 200 pada daerah beriklim basah di Kebun Aek Tarum, Kabupaten Asahan

Table 1. Description of adaptation test of IRR 200 series clone in wet climate at Aek Tarum Estate, Asahan District

\begin{tabular}{|c|c|c|}
\hline No & $\begin{array}{l}\text { Keterangan } \\
\text { Remarks }\end{array}$ & $\begin{array}{c}\text { Lokasi Pengujian } \\
\text { di Kebun Aek Tarum } \\
\text { Trial location } \\
\text { at Aek Tarum Estate }\end{array}$ \\
\hline 1. & $\begin{array}{l}\text { Tahun tanam } \\
\text { Planting year }\end{array}$ & 2010 \\
\hline 2. & $\begin{array}{l}\text { Klon yang diuji } \\
\text { Tested Clones }\end{array}$ & $\begin{array}{l}\text { IRR 205, IRR 208, IRR 210, IRR } \\
215 \text {, IRR } 218, \text { IRR } 219, \text { IRR } 220 \\
\text { dan klon pembanding PB } 260\end{array}$ \\
\hline 3. & $\begin{array}{l}\text { Rancangan percobaan } \\
\text { Experimental design }\end{array}$ & $\begin{array}{l}\text { Rancangan Augmented dalam } \\
\text { RAK (Augmented design in } R C B D \text { ) }\end{array}$ \\
\hline 4. & $\begin{array}{l}\text { Jarak tanam } \\
\text { Planting distance }\end{array}$ & $5 \times 4 \mathrm{~m}$ \\
\hline 5. & $\begin{array}{l}\text { Luas plot } \\
\text { Plot size }\end{array}$ & 0,5 ha \\
\hline 6. & $\begin{array}{l}\text { Jumlah tanaman/ plot } \\
\text { Number of trees/ plot }\end{array}$ & 250 pohon (trees) \\
\hline 7. & $\begin{array}{l}\text { Luas Percobaan } \\
\text { Hectarage }\end{array}$ & 8 ha \\
\hline 8. & $\begin{array}{l}\text { Topografi } \\
\text { Topography }\end{array}$ & Berbukit (hilling) \\
\hline 9. & $\begin{array}{l}\text { Tinggi tempat } \\
\text { Elevation }\end{array}$ & $\pm 210 \mathrm{~m} \mathrm{dpl}$ (above sea level) \\
\hline 10. & $\begin{array}{l}\text { Jenis tanah } \\
\text { Soil type }\end{array}$ & Ultisol \\
\hline 11. & $\begin{array}{l}\text { Tekstur tanah } \\
\text { Soil texture }\end{array}$ & $\begin{array}{l}\text { Lempung liat berpasir } \\
\text { Sandy clay loam }\end{array}$ \\
\hline 12. & $\begin{array}{l}\text { Rata-rata curah hujan } \\
\text { Rainfall average }\end{array}$ & $2899 \mathrm{~mm} / \mathrm{th}(\mathrm{mm} / \mathrm{yr})$ \\
\hline 13. & $\begin{array}{l}\text { Jumlah hari hujan } \\
\text { Number of raindays }\end{array}$ & 186 hari/th (days/yr) \\
\hline
\end{tabular}


Lilit batang, diukur pada ketinggian $130 \mathrm{~cm}$ di atas pertautan okulasi dengan menggunaakan alat meteran kain (ukuran $100 \mathrm{~cm})$.

Tebal kulit, contoh kulit diambil dengan menggunakan alat pelubang kulit yang terbuat dari besi dengan diameter $1 \mathrm{~cm}$. Alat yang digunakan untuk mengukur ketebalan kulit adalah caliper. Sampel kulit diambil tepat dengan sudut awal bidang sadap pada ketinggian $130 \mathrm{~cm}$ di atas pertautan okulasi.

Jumlah cincin pembuluh lateks, pengamatan jumlah cincin pembuluh lateks dilakukan menurut metode Gomez et al. (1972). Fiksasi contoh kulit dilakukan dengan larutan FAA (Formalin Acetic Acid). Pembuatan preparat semi permanen yaitu dengan cara kulit hasil fiksasi dimasukkan ke dalam larutan $\mathrm{KOH} 15 \%$ selama 1 jam, kemudian dibilas dengan air mengalir selama 5 menit dan dikering-anginkan. Selanjutnya preparat direndam kembali ke dalam larutan $\mathrm{HNO}_{3}$ selama 2 jam, setelah itu dibilas kembali dengan menggunakan air mengalir selama 5 menit kemudian dikeringanginkan. Proses selanjutnya preparat direndam kembali ke dalam larutan alkohol $70 \%$ selama 15 menit, setelah itu dibilas kembali dengan air mengalir serta dikeringanginkan. Pewarnaan preparat menggunakan Sudan III dengan cara direndam selama 30 menit. Kemudian preparat diiris dengan menggunakan pisau silet secara membujur untuk melihat jumlah cincin pembuluh lateks. Masing-masing irisan tipis dari preparat tersebut diletakkan di gelas objek dan ditutup dengan gelas penutup (cover glass) yang sebelumnya diberi gliserin untuk menjaga agar preparat tersebut tidak mengering. Pengamatan dilakukan di bawah mikroskop cahaya.

Diameter sel pembuluh lateks, untuk mengukur diameter sel pembuluh lateks digunakan metode Gomez et al. (1972). Seperti halnya pada pengamatan pada jumlah cincin pembuluh lateks, maka untuk melihat ukuran diameter sel pembuluh lateks preparat diiris secara melintang. Masing-masing irisan tipis dari preparat tersebut diletakkan di gelas objek dan ditutup dengan gelas penutup (cover glass) yang sebelumnya diberi gliserin agar menjaga preparat tersebut tidak mengering. Pengamatan dilakukan di bawah mikroskop cahaya.

Intensitas serangan penyakit gugur daun, pengamatan tingkat resistensi klon terhadap penyakit gugur daun dilakukan dengan cara observasi langsung di lapang. Observasi langsung dilakukan karena lokasi pengujian di Kebun Aek Tarum memiliki iklim tergolong cukup basah, sehingga berpeluang untuk berkembangbiaknya penyakit penyebab gugur daun tanaman karet. Tiga jenis

Tabel 2. Nilai bercak dan cacat daun serangan penyakit gugur daun Colletotrichum

Table 2. Spots and leaves damage value of Colletotrichum leaffall disease attack

\begin{tabular}{|c|c|}
\hline $\begin{array}{l}\text { Skor } \\
\text { Score }\end{array}$ & $\begin{array}{l}\text { Keterangan } \\
\text { Remarks }\end{array}$ \\
\hline 0 & $\begin{array}{l}\text { Tidak terdapat bercak atau cacat pada daun } \\
\text { There are no spots or damage on leaves }\end{array}$ \\
\hline 1 & $\begin{array}{l}\text { Terdapat bercak atau cacat pada daun } 1 / 16 \text { bagian } \\
\text { There are spots or damage on } 1 / 16 \text { part of leaves }\end{array}$ \\
\hline 2 & $\begin{array}{l}\text { Terdapat bercak atau cacat pada daun } 1 / 8 \text { bagian } \\
\text { There are spots or damage on } 1 / 8 \text { part of leaves }\end{array}$ \\
\hline 3 & $\begin{array}{l}\text { Terdapat bercak atau cacat pada daun } 1 / 4 \text { bagian } \\
\text { There are spots or damage on } 1 / 4 \text { part of leaves }\end{array}$ \\
\hline 4 & $\begin{array}{l}\text { Terdapat bercak atau cacat pada daun } 1 / 2 \text { bagian } \\
\text { There are spots or damage on } 1 / 2 \text { part of leaves }\end{array}$ \\
\hline 5 & $\begin{array}{l}\text { Terdapat bercak atau cacat pada daun }>1 / 2 \text { bagian } \\
\text { There are spots or damage on }>1 / 2 \text { part of leaves }\end{array}$ \\
\hline 6 & $\begin{array}{l}\text { Daun gugur total } \\
\text { Total leaf fall }\end{array}$ \\
\hline
\end{tabular}


Tabel 3. Nilai bercak serangan penyakit gugur daun Oidium Table 3. Spots value of Oidium leaffall disease

\begin{tabular}{cl}
$\begin{array}{c}\text { Skor } \\
\text { Score }\end{array}$ & \multicolumn{1}{c}{$\begin{array}{c}\text { Keterangan } \\
\text { Remarks }\end{array}$} \\
\hline 0 & $\begin{array}{l}\text { Tidak terdapat bercak pada daun } \\
\text { There are no spots on leaves } \\
\text { Terdapat bercak 1/ 16 bagian pada daun }\end{array}$ \\
$\begin{array}{l}\text { There are spots on 1/16 part of leaves } \\
\text { Terdapat bercak 1/8 bagian pada daun }\end{array}$ & $\begin{array}{l}\text { There are spots on 1/8 part of leaves } \\
\text { Terdapat bercak 1/4 bagian pada daun }\end{array}$ \\
& $\begin{array}{l}\text { There are spots on 1/4 part of leaves } \\
\text { Terdapat bercak 1/2 bagian pada daun }\end{array}$ \\
5 & $\begin{array}{l}\text { There are spots on 1/2 part of leaves } \\
\text { Terdapat bercak }>1 / 2 \text { bagian }\end{array}$ \\
& $\begin{array}{l}\text { There are spots }>1 / 2 \text { part of leaves } \\
\text { Terdapat bercak pada seluruh permukaan daun } \\
\text { There are spots on entire surface of leaves }\end{array}$ \\
\hline
\end{tabular}

Tabel 4. Nilai bercak serangan penyakit gugur daun Corynespora Table 4. Spots value of Corynespora leaf fall disease attack

\begin{tabular}{|c|c|}
\hline $\begin{array}{l}\text { Skor } \\
\text { Score }\end{array}$ & $\begin{array}{l}\text { Keterangan } \\
\text { Remarks }\end{array}$ \\
\hline 0 & $\begin{array}{l}\text { Tidak terdapat bercak pada urat/tulang daun } \\
\text { There are no spots on veining/bone leaves }\end{array}$ \\
\hline 1 & $\begin{array}{l}\text { Terdapat satu-tiga bercak pada urat daun } \\
\text { There are one-three spots on veining leaves }\end{array}$ \\
\hline 2 & $\begin{array}{l}\text { Terdapat beberapa bercak } \leq 1 / 2 \text { bagian daun } \\
\text { There are some spots on } \leq 1 / 2 \text { part of leaves }\end{array}$ \\
\hline 3 & $\begin{array}{l}\text { Terdapat bercak pada tulang / urat daun menyebabkan } \leq 1 / 2 \text { daun } \\
\text { menguning }\end{array}$ \\
\hline 4 & $\begin{array}{l}\text { Terdapat bercak pada tulang / urat daun menyebabkan }>1 / 2 \text { daun } \\
\text { menguning } \\
\text { There are spots on bone/ veining leaves cause }>1 / 2 \text { part of leaves } \\
\text { yellowing }\end{array}$ \\
\hline 5 & $\begin{array}{l}\text { Daun gugur total } \\
\text { Total leaf fall }\end{array}$ \\
\hline
\end{tabular}

penyakit gugur daun yang diamati pada penelitian ini, yaitu penyakit gugur daun Colletotrichum, Oidium, dan Corynespora. Penilaian skala bercak dan cacat daun untuk ketiga penyakit gugur daun tersebut, dilakukan dengan menggunakan rumus yang dikembangkan oleh Pawirosoemardjo (1999) seperti yang disajikan pada Tabel 2, 3, dan 4.

Intensitas serangan penyakit gugur daun dihitung sebagai berikut :

$$
I=\frac{\sum(\mathrm{n} \times \mathrm{v})}{Z \times N} \times 100 \%
$$

Dimana,

I : intensitas serangan

$\mathrm{N}$ : jumlah daun tiap kategori serangan

$\mathrm{V}$ : nilai skala dari setiap kategori serangan

Z : nilai skala tertinggi dari kategori serangan

$\mathrm{N}$ : jumlah daun yang diamati

Penilaian kualitatif ketahanan klon terhadap serangan penyakit gugur daun ditentukan berdasarkan nilai intensitas serangan, dengan kriteria sebagai berikut :
Resisten
: $0-20 \%$
Moderat resisten : : $21-40 \%$
Moderat $\quad: 41-60 \%$ 


$$
\begin{array}{ll}
\text { Moderat rentan } & : 61-80 \% \\
\text { Rentan } & : 81-100 \%
\end{array}
$$

Analisis data pengamatan untuk pertumbuhan tanaman dilakukan dengan menggunakan statistik dengan memanfaatkan program MINITAB ver. 16 untuk menghitung nilai tengah, minimum, maksimum, standar deviasi dan koefisien keragaman dari masing-masing klon. Untuk mengetahui tingkat kejaguran pada klon IRR seri 200, maka dilakukan dengan cara membandingkan rata-rata lilit batang masing-masing klon IRR seri 200 dengan klon kontrol PB 260 dalam bentuk presentase.

\section{HASIL DAN PEMBAHASAN}

\section{Kondisi Curah Hujan dan Hari Hujan}

Kondisi curah hujan dan hari hujan di Kebun Aek Tarum tergolong cukup tinggi selama delapan tahun terakhir. Rata-rata curah hujan di kebun tersebut sebesar 2899 $\mathrm{mm} /$ th dan hari hujan sebanyak 186 hari/th. Kondisi curah hujan dan hari hujan di lokasi pengujian tersebut dapat digolongkan sebagai daerah kurang optimal untuk budidaya tanaman karet. Menurut Darmandono (1995), rata-rata curah hujan yang terbaik untuk mendukung produktivitas tanaman karet adalah 1.800$2.500 \mathrm{~mm} /$ th dengan hari hujan sebanyak 115-150 hari/th. Kondisi curah hujan tinggi akan menekan pertumbuhan tanaman akibat serangan penyakit gugur daun terutama Colletotrichum, Oidium, dan Corynepsora. Kondisi curah hujan dan hari hujan serta sebarannya selama delapan tahun terakhir di kebun Aek Tarum disajikan pada Gambar 1 dan 2.

Klon IRR seri 200 yang di bangun pada tahun 2010 di Kebun Aek Tarum mendapatkan cekaman cukup nyata terhadap kondisi curah hujan (>2500 $\mathrm{mm} / \mathrm{th})$ terutama pada tahun 2012 dan 2013. Rata-rata curah hujan dan hari hujan pada tahun tersebut cukup tinggi dengan jumlah curah hujan $>3500 \mathrm{~mm} /$ th dan jumlah hari hujan $>240$ hari/th. Pada kondisi tersebut ternyata sebagian klon IRR seri 200 masih memiliki pertumbuhan cukup baik pada masa TBM seperti klon IRR 205, IRR 210, IRR 215, IRR 219, dan IRR 220. Pada umur empat tahun, klon-klon tersebut sudah memenuhi kriteria matang sadap dengan ukuran lilit batang $>45 \mathrm{~cm}$ (Tabel 5).

Berdasarkan karakter pertumbuhan tanaman, ternyata klon IRR seri 200 memiliki adaptasi cukup baik pada daerah beriklim basah. Dari beberapa hasil penelitian sebelumnya juga menyimpulkan bahwa pertumbuhan beberapa klon karet ternyata lebih baik di daerah curah hujan sedang sampai dengan tinggi tetapi memiliki 2-3 bulan kering yang tegas (Aidi- Daslin et al., 1997; Aidi-Daslin, 2011). Selain itu, manajemen di perkebunan di lokasi penelitian juga cukup baik dalam
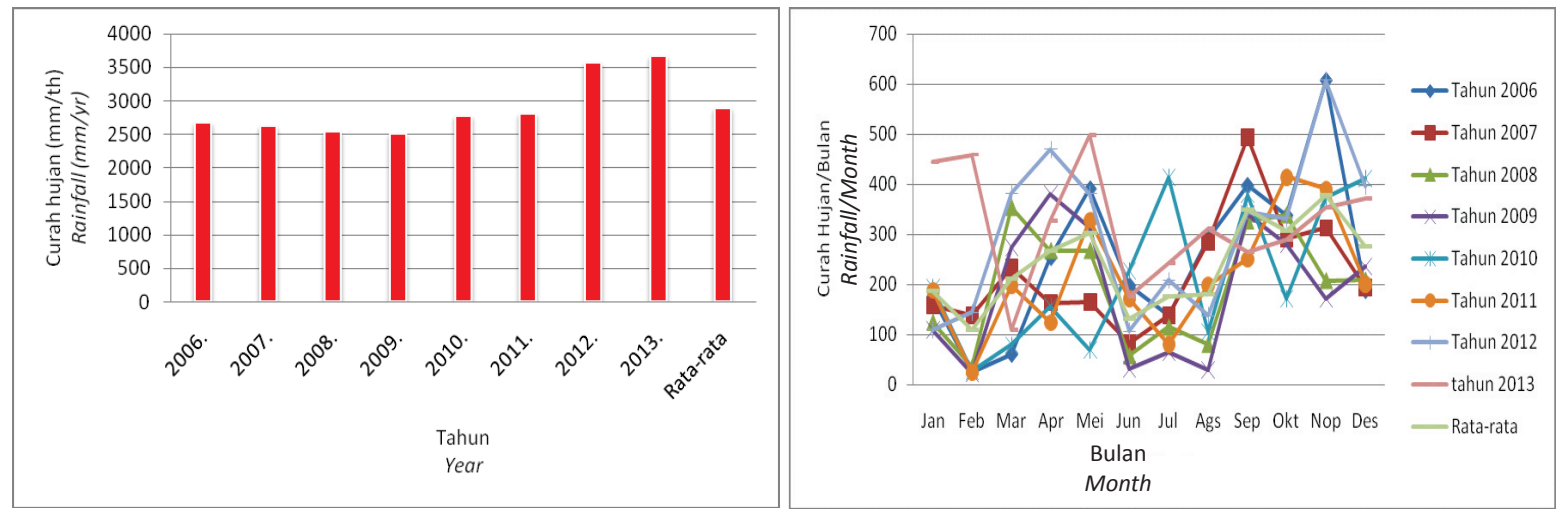

Gambar 1. Jumlah curah hujan ( $\mathrm{mm} /$ tahun) dan sebaran curah hujan bulanan ( $\mathrm{mm} /$ bulan) di Kebun Aek Tarum selama delapan tahun terakhir

Figure 1. Number of rainfall ( $\mathrm{mm} /$ year) and distribution of rainfall monthly $(\mathrm{mm} / \mathrm{month})$ at Aek Tarum Estate for the past eight years 

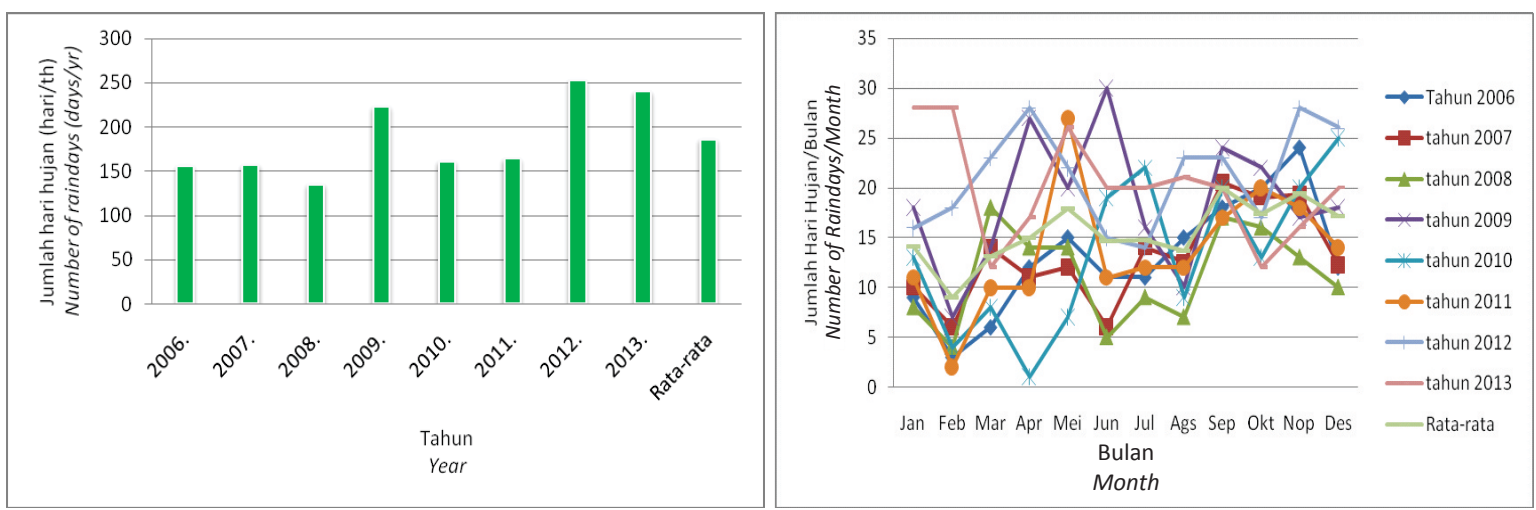

Gambar 2. Jumlah hari hujan (hari/tahun) dan sebaran hari hujan bulanan (hari/bulan) di Kebun Aek Tarum selama delapan tahun terakhir

Figure 2. Number of raindays (days/year) and distribution of monthly raindays (days/month) at Aek Tarum Estate for the past eight years

Tabel 5. Ukuran lilit batang dan laju pertumbuhan klon karet harapan IRR seri 200 di Kebun Aek Tarum, Kabupaten Asahan.

Table 5. Girth size and growth increment of IRR 200 series promising rubber clones at Aek Tarum Field, Asahan District

\begin{tabular}{|c|c|c|c|c|c|}
\hline \multirow{2}{*}{$\begin{array}{l}\text { Klon } \\
\text { Clones }\end{array}$} & \multicolumn{4}{|c|}{$\begin{array}{l}\text { Lilit batang }(\mathrm{cm}) \text {, umur } \\
\text { Girth }(\mathrm{cm}) \text {, age }\end{array}$} & \multirow{2}{*}{$\begin{array}{l}\text { Pertambahan lilit } \\
\text { batang }(\mathrm{cm} / \mathrm{th}) \\
\text { Girth } \\
\text { increment }(\mathrm{cm} / \mathrm{yr})\end{array}$} \\
\hline & $\begin{array}{l}1 \mathrm{th} \\
1 \mathrm{yr}\end{array}$ & $\begin{array}{l}2 \text { th } \\
2 y r\end{array}$ & $\begin{array}{l}3 \text { th } \\
3 y r\end{array}$ & $\begin{array}{l}4 \text { th } \\
4 y r\end{array}$ & \\
\hline IRR 205 & 14,40 & 26,80 & 36,55 & $46,30(104)$ & $11,08(105)$ \\
\hline IRR 208 & 13,45 & 25,50 & 34,60 & $43,70(98)$ & $10,24(97)$ \\
\hline IRR 210 & 13,42 & 26,70 & 37,80 & $48,90(110)$ & $12,68(120)$ \\
\hline IRR 215 & 13,65 & 23,70 & 34,50 & $45,30(102)$ & $10,43(98)$ \\
\hline IRR 218 & 12,55 & 26,00 & 34,50 & $43,00(96)$ & $10,12(96)$ \\
\hline IRR 219 & 13,75 & 28,00 & 37,05 & $46,10(103)$ & $11,65(110)$ \\
\hline IRR 220 & 14,45 & 25,70 & 35,80 & $45,90(102)$ & $11,02(104)$ \\
\hline PB 260 & 13,38 & 27,00 & 35,10 & $44,60(100)$ & $10,59(100)$ \\
\hline $\begin{array}{l}\text { Rata-rata } \\
\text { Average }\end{array}$ & 13,51 & 26,18 & 35,74 & 45,48 & 11,12 \\
\hline $\begin{array}{l}\text { Minimum } \\
\text { Minimum }\end{array}$ & 12,45 & 23,70 & 34,50 & 43,00 & 10,43 \\
\hline $\begin{array}{l}\text { Maksimum } \\
\text { Maximum }\end{array}$ & 14,45 & 28,00 & 37,80 & 48,90 & 12,68 \\
\hline $\begin{array}{l}\text { Simpangan baku } \\
\text { Standard deviation }\end{array}$ & 0,74 & 1,28 & 1,28 & 1,81 & 0,74 \\
\hline $\begin{array}{l}\text { Koefisien keragaman } \\
\text { (Coefficient of } \\
\text { variation) }\end{array}$ & 5,93 & 5,41 & 3,70 & 4,22 & 7,09 \\
\hline
\end{tabular}

Angka-angka didalam kurung adalah persentase pertumbuhan terhadap klon PB 260

Figures in brackets are percentage of growth compared with PB 260 
pemeliharaan tanaman, sehingga klon IRR seri 200 yang diuji memiliki pertumbuhan jagur pada masa TBM. Berdasarkan pertumbuhan tanaman, klon IRR seri 200 yang berpeluang untuk dikembangkan pada daerah beriklim basah yaitu IRR 205, IRR 210, IRR 215, IRR 219, dan IRR 220.

\section{Pertumbuhan Tanaman}

Data pertumbuhan tanaman klon IRR seri 200 disajikan pada Tabel 5. Dari tabel tersebut diketahui bahwa pada umumnya klon IRR seri 200 yang ditanam di kebun Aek Tarum memiliki pertumbuhan cukup jagur dan homogen dengan koefisien keragaman (KK) berkisar 3,70 - 5,93\%. Ratarata ukuran lilit batang klon IRR seri 200 pada umur satu tahun yaitu sebesar 13,51 $\mathrm{cm}$ dengan kisaran 12,05 - 14,45 cm. Klon IRR 205 dan IRR 220 memiliki pertumbuhan paling jagur pada umur satu tahun dengan ukuran lilit batang masing-masing sebesar $14,40 \mathrm{~cm}$ dan $14,45 \mathrm{~cm}$, sedangkan klon IRR 218 memiliki pertumbuhan paling lambat dengan ukuran lilit batang sebesar 12,55 $\mathrm{cm}$, namun klon tersebut masih tergolong jagur. Siagian et al. (2005) menyatakan bahwa ukuran lilit batang tanaman karet pada umur satu tahun $>11 \mathrm{~cm}$ dapat dimasukkan dalam kategori tergolong jagur.
Tabel 5 menunjukkan bahwa pada umur dua tahun klon IRR 220 dan PB 260 memiliki pertumbuhan lilit batang paling jagur dibandingkan dengan klon lainnya, dengan ukuran lilit batang masing-masing sebesar $28 \mathrm{~cm}$ dan $27 \mathrm{~cm}$. Sedangkan, pada umur tiga tahun klon IRR 210 dan IRR 219 memiliki pertumbuhan lilit batang paling jagur dengan ukuran lilit batang masingmasing sebesar $37,80 \mathrm{~cm}$ dan $37,05 \mathrm{~cm}$. Tabel 5 juga menunjukkan bahwa rata-rata pertumbuhan lilit batang klon IRR seri 200 pada umur empat tahun sebesar $45,48 \mathrm{~cm}$ dengan kisaran $43-48,9 \mathrm{~cm}$. Klon IRR 205, IRR 210, IRR 215, IRR 219, dan IRR 220 memiliki pertumbuhan jagur dengan persentase sebesar $102-110 \%$ terhadap klon PB 260. Klon IRR 208 dan IRR 218 memiliki pertumbuhan lebih lambat dengan ukuran lilit batang masing-masing sebesar $43,70 \mathrm{~cm}$ dan $43,00 \mathrm{~cm}$ atau $96-98 \%$ terhadap klon PB 260. Histogram ukuran lilit batang pada umur empat tahun dan pertambahan lilit batang tanaman pada klon IRR seri 200 disajikan pada Gambar 3.

Laju pertumbuhan tanaman pada klon IRR seri 200 pada umumnya tergolong jagur. Rata-rata pertambahan lilit batang tanaman selama empat tahun sebesar 11,12 $\mathrm{cm} /$ th dengan kisaran $10,43-12,68 \mathrm{~cm} /$ th .

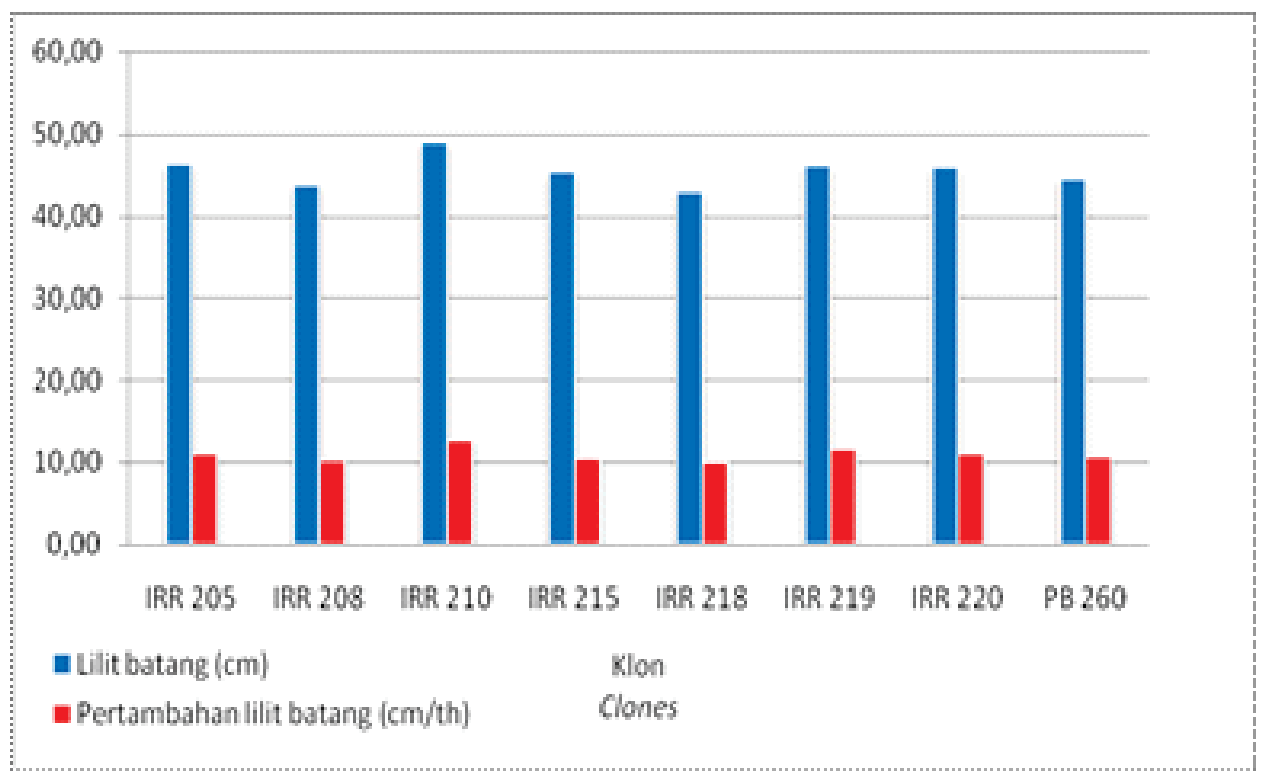

Gambar 3. Histogram ukuran lilit batang dan pertambahan lilit batang tanaman klon IRR seri 200 pada umur 4 tahun

Figure 3. Histograms of girth and plant girth increment of IRR 200 series clone at 4 years old 
Klon IRR 205, IRR 2 10, IRR 219, dan IRR 220 memiliki laju pertambahan lilit batang tanaman paling tinggi yaitu masing-masing sebesar $11,08 \mathrm{~cm} / \mathrm{th}, 12,68 \mathrm{~cm} / \mathrm{th}, 11,65$ $\mathrm{cm} /$ th , dan $11,02 \mathrm{~cm} /$ th atau $104-120 \%$ terhadap klon PB 260. Klon IRR seri 200 yang memiliki laju pertambahan lilit batang paling lambat yaitu klon IRR 208 dan IRR 218. Menurut Aidi-Daslin (2005), klon jagur memiliki pertumbuhan awal cepat selama masa TBM dengan rata-rata pertambahan lilit batang tanaman lebih dari $11 \mathrm{~cm} / \mathrm{th}$. Dengan demikian, klon IRR seri 200 yang ditanam di Kebun Aek Tarum pada umumnya masih tergolong jagur, kecuali pada klon IRR 208 dan IRR 218.

\section{Ukuran Tebal Kulit, Jumlah Cincin Pembuluh Lateks dan Diameter Sel Pembuluh Lateks}

Beberapa karakter klon selain pertumbuhan yang diketahui penting sebagai parameter seleksi diantaranya adalah karakter tebal kulit dan anatomi kulit. Karakter anatomi kulit yang diamati adalah jumlah cincin pembuluh lateks dan diameter sel pembuluh lateks. Karakterkarakter penting tersebut perlu diketahui karena sebagian besar proses biosintesis lateks terjadi di dalam jaringan kulit. Goncalves et al. (2005) menyatakan bahwa produksi karet dipengaruhi oleh sejumlah karakter komponen hasil seperti tebal kulit, jumlah cincin pembuluh lateks, dan diameter sel pembuluh lateks serta sifat fisiologi lainnya. Novalina (2009) menyatakan bahwa tebal kulit dan jumlah cincin pembuluh lateks memiliki pengaruh positif terhadap hasil lateks pada genotipe hasil persilangan antara klon PB 260 dan PN 7111 , sedangkan Woelan (2013) menyatakan bahwa ukuran lilit batang, tebal kulit, jumlah cincin pembuluh lateks, dan jumlah partikel karet memiliki korelasi positif terhadap hasil lateks pada genotipe hasil persilangan antara RRIM 600 dan PN 1546. Histogram ukuran tebal kulit, jumlah cincin pembuluh lateks dan diameter sel pembuluh lateks disajikan pada Gambar 4.

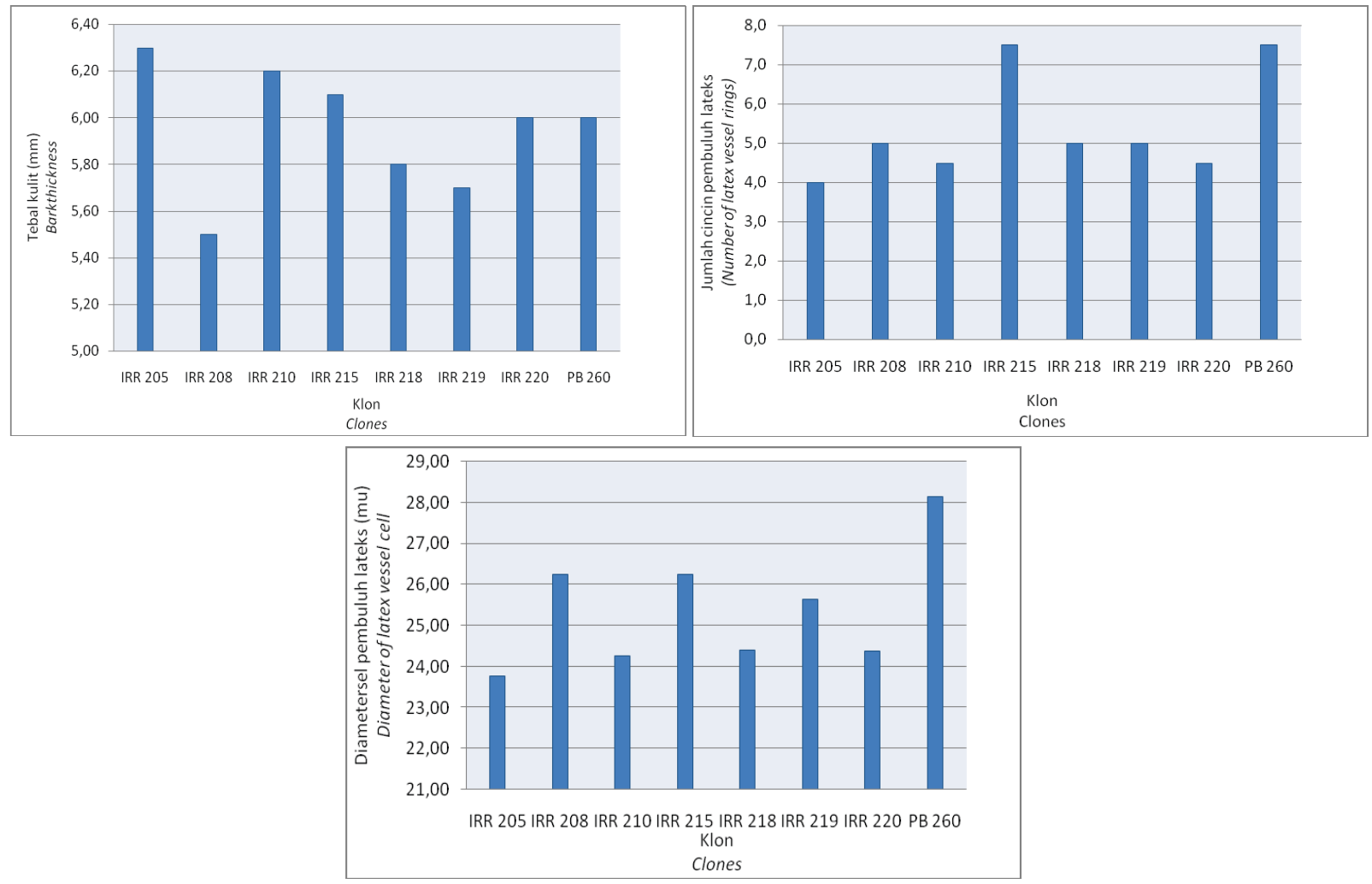

Gambar 4. Histogram tebal kulit, jumlah cincin pembuluh lateks, dan diameter sel pembuluh lateks pada klon IRR seri 200

Figure 4. Histograms of bark thickness, number of latex vessel rings and diameter of latex vessel cell of IRR 200 series clone 
Gambar 4 menunjukkan bahwa ratarata tebal kulit klon IRR seri 200 yang diuji cukup beragam. Klon IRR 205, IRR 210, dan 215 pada umur 4 tahun memiliki ukuran tebal kulit paling tinggi, yaitu $\geq 6,0 \mathrm{~mm}$, sedangkan klon IRR 208, IRR 218, dan IRR 219 memiliki ukuran tebal kulit tergolong rendah $(<5,8 \mathrm{~mm})$. Klon IRR 220 dan PB 260 memiliki ukuran tebal kulit sebesar 6,0 mm. Gambar 4 juga menunjukkan bahwa berdasarkan karakter jumlah cincin pembuluh lateks tampak bahwa klon IRR 215 dan PB 260 memiliki jumlah cincin pembuluh lateks paling tinggi, sedangkan klon IRR 205 memiliki jumlah cincin pembuluh lateks paling sedikit dibandingkan dengan klon lainnya.

Pada karakter diameter sel pembuluh lateks tampak bahwa pada umumnya klon IRR seri 200 memiliki diameter sel pembuluh lateks $\geq 24,0 \mu \mathrm{m}$ (Gambar 4). Klon PB 260 memiliki diameter sel pembuluh lateks paling tinggi yaitu > 28,0 $\mu \mathrm{m}$, sedangkan klon IRR 205 memiliki diameter sel pembuluh lateks paling rendah $(<24,0 \mu \mathrm{m})$. Klon IRR 208, IRR 215, dan IRR 219 memiliki diameter sel pembuluh lateks $>26,0 \mu \mathrm{m}$. Dengan demikian, klon karet IRR seri 200 yang memiliki karakter anatomi kulit yang baik, diharapkan berpotensi menghasilkan produksi karet tinggi.

\section{Resistensi Penyakit Gugur Daun}

Informasi ketahanan klon IRR seri 200 terhadap penyakit gugur daun pada tanaman karet sangat penting diketahui khususnya untuk daerah dengan curah hujan tinggi yang merupakan lingkungan yang sesuai untuk penyebaran penyakit gugur daun. Pada makalah ini melaporkan informasi ketahanan penyakit gugur daun pada klon IRR seri 200 pada fase TBM. Hasil pengamatan terhadap penyakit gugur daun Colletotrichum, Oidium, dan Corynespora pada tanaman umur 3 dan 4 tahun disajikan pada Gambar 5, 6 dan 7. Kondisi jumlah curah hujan dan hari hujan pada pengamatan penyakit pada umur 3 tahun tergolong tinggi dengan jumlah curah hujan sebesar $3675 \mathrm{~mm} / \mathrm{th}$ dan jumlah hari hujan sebanyak 250 hari/th (Gambar 1 dan 2). Pada kondisi tersebut, ternyata sebagian klon IRR seri 200 memiliki ketahanan penyakit tergolong moderat - resisten terhadap penyakit gugur daun.

Gambar 5 menunjukkan bahwa klon karet IRR seri 200 yang diuji di Kebun Aek Tarum pada umumnya memiliki ketahahan penyakit tergolong moderat sampai resisten terhadap penyakit gugur daun Colletotrichum dengan nilai intensitas serangan di bawah 30\%. Klon IRR 208 dan

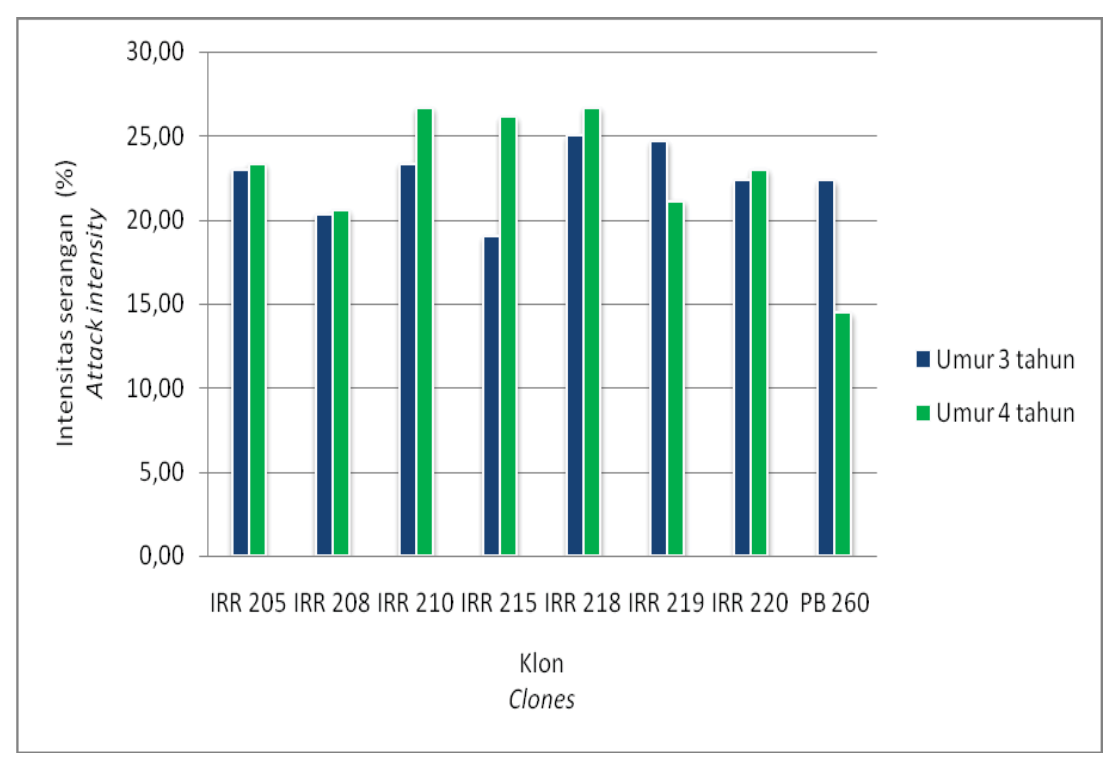

Gambar 5. Ketahanan klon IRR seri 200 terhadap penyakit gugur daun Colletotrichum Figure 5. Resistance of IRR 200 series clone to Colletotrichum leaf fall diseases 
Uji Adaptasi Klon Karet Harapan IRR Seri 200 Pada Masa Tanaman Belum Menghasilkan di Daerah Beriklim Basah, Kebun Aek Tarum-Kabupaten Asahan

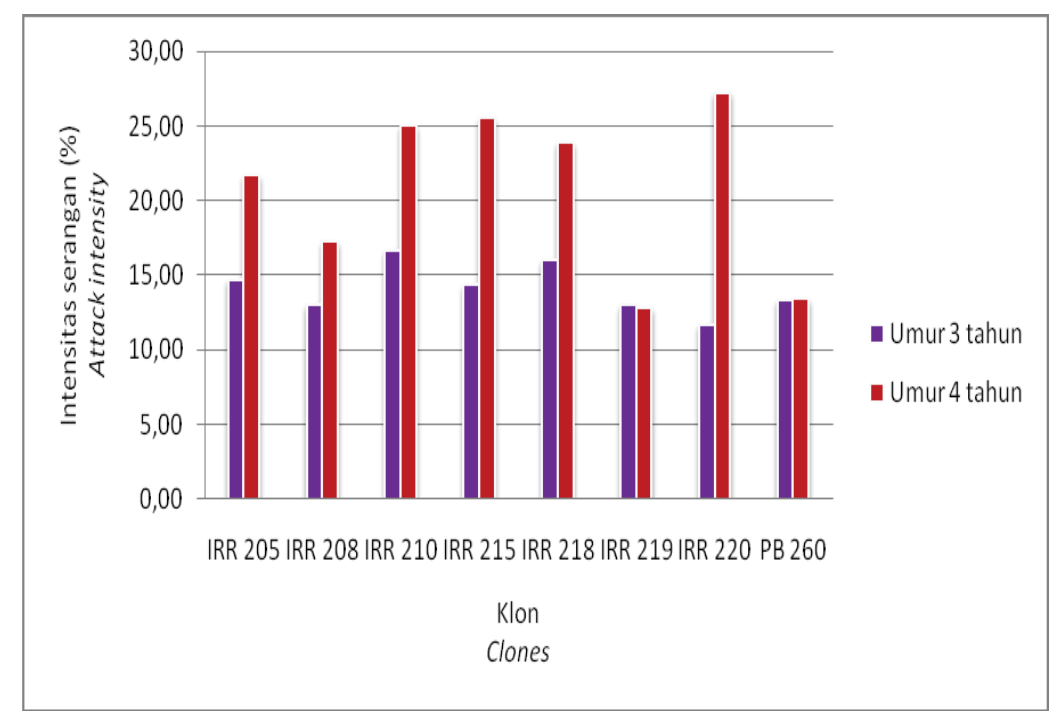

Gambar 6. Ketahanan klon IRR seri 200 terhadap penyakit gugur daun Oidium Figure 6. Resistance of IRR 200 series clone to Oidium leaf fall diseases

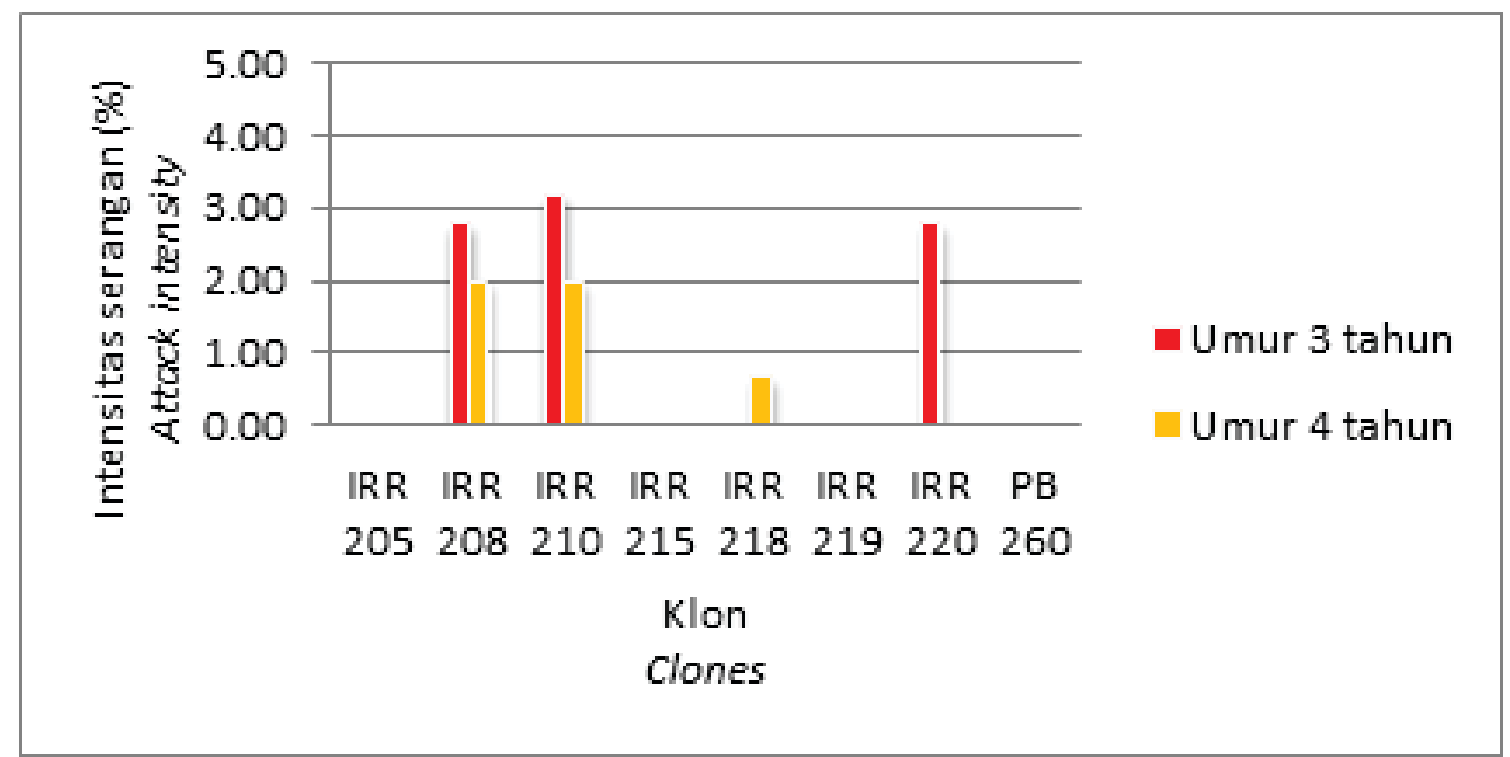

Gambar 7. Ketahanan klon IRR seri 200 terhadap penyakit gugur daun Corynespora Figure 7. Resistance of IRR 200 series clone to Corynespora leaf fall diseases

PB 260 memiliki ketahanan penyakit gugur daun paling tinggi dengan intensitas serangan masing-masing $20 \%$ dan $15 \%$. Pada Gambar 6 juga menunjukkan ketahanan penyakit gugur daun Oidium yang cukup resisten pada umur 3 tahun, tetapi pada umur 4 tahun nampak gejala klon IRR seri 200 yang tergolong moderat resisten sampai dengan resisten di antaranya yaitu klon IRR 205, IRR 210, IRR
215, IRR 218, dan IRR 220. Sedangkan, klon IRR 208, IRR 219, dan PB 260 tergolong resisten terhadap penyakit gugur daun Oidium. Tingginya serangan penyakit gugur daun Oidium pada umur 4 tahun diduga diakibatkan intensitas curah hujan lebih tinggi terjadi pada saat TBM-4 dibandingkan pada TBM tahun sebelumnya. Curah hujan dan kelembaban tinggi berakibat terhadap perkembangbiakan jamur Oidium semakin 
tinggi, namun infeksi dengan nilai serangan tersebut masih di bawah ambang toleransi. Untuk ketahanan penyakit Corynespora (Gambar 7), klon IRR seri 200 masih tergolong resisten dengan intensitas serangan penyakit $<5 \%$.

\section{KESIMPULAN}

Klon IRR 205, IRR 210, IRR 215, IRR 219, dan IRR 220 memiliki pertumbuhan jagur pada daerah beriklim basah jumlah curah hujan sebesar $2899 \mathrm{~mm} /$ th dan hari hujan sebanyak 186 hari/th). Rata-rata ukuran lilit batang pada umur empat tahun mencapai $>45 \mathrm{~cm}$. Dengan demikian masa tanaman belum menghasilkan (TBM) klon IRR seri 200 dapat dipersingkat menjadi $\leq$ empat tahun. Klon IRR seri 200 juga mempunyai sifat sekunder yang lebih baik diantaranya ketahanan terhadap penyakit gugur daun. Pengamatan terhadap karakter pertumbuhan dan produksi karet saat ini sedang berlangsung. Diharapkan akan terseleksi klon karet IRR seri 200 yang beradaptasi baik dan berproduksi tinggi pada iklim basah.

\section{UCAPAN TERIMAKASIH}

Pada kesempatan ini disampaikan terimakasih kepada Kemenristek atas pemberian dana insentif Riset SINas 2014 dengan nomor kontrak: 10/SEK/ INSINAS/PPK/I/2014. Ucapan terimakasih juga kami tujukan kepada para Pimpinan Kebun Aek Tarum dan Teknisi di bagian Unit Penelitian, Perbaikan dan Proteksi Tanaman, Balai Penelitian Sungei Putih.

\section{DAFTAR PUSTAKA}

Aidi-Daslin, I. Suhendry, dan R. Azwar. 1997. Produktivitas Perkebunan Karet Dalam Hubungannya dengan Jenis Klon dan Agroklimat. Kumpulan Makalah Apresiasi Teknologi Peningkatan Produktivitas Lahan Perkebunan Karet. Pusat Penelitian Karet.: 201-215.
Aidi-Daslin, 2005. Kemajuan Pemuliaan dan Seleksi dalam Menghasilkan Kultivar Karet Unggul. Pros. Lok. Nas. Pemuliaan Tanaman Karet 2005. Medan, 22 - 23 November. Pusat Penelitian Karet.: 26-37.

Aidi-Daslin dan Sayurandi. 2006. Pengaruh Interaksi Genotipe dan Lingkungan Terhadap Pertumbuhan dan Produksi Klon IRR Seri 100 Pada Uji Lanjutan. Jurnal Penelitian Karet 24(2): 91-100.

Aidi-Daslin, Sayurandi and Sekar Woelan. 2007. Adaptability and Stability of IRR 100-series Rubber Clones. Proc. International Rubber Conference \& Exhibition 2007. Bali, 13 - 15 Juni. IRRDB-IRRI.: 385-392.

Aidi-Daslin, S. Woelan, M. Lasminingsih dan H. Hadi. 2009. Kemajuan Pemuliaan dan Seleksi Tanaman Karet di Indonesia. Pros. Lok. Nas. Pemuliaan Tanaman Karet 2009. Batam, 24-26 Agustus. Pusat Penelitian Karet.: 5059.

Aidi-Daslin. 2011. Evaluasi Pengujian Lanjutan Klon Karet IRR Seri 200 Pada Masa Tanaman Belum Menghasilkan. Jurnal Penelitian Karet 29 (2): 93 - 101.

Basuki, S. Pawirosoemardjo, U. Nasution, Sutardi, W. Sinulingga dan A. Situmorang. 1990. Penyakit Gugur Daun Colletotrichum pada Tanaman Karet di Indonesia. Potensi, Penyebaran dan Penanggulangannya. Pros. Lok. Nas. Pemuliaan Tanaman Karet 1990. Pontianak, 14 - 17 Juli. Pusat Penelitian Karet.: 268-295.

Darmandono. 1995. Pengaruh Komponen Hujan terhadap Produktivitas Karet. Jurnal Penelitian Karet 13(3): 223-238.

Gomez, J,. R. Narayanan, and K. T. Chen. 1972. Some Structural Factors Affecting the Productivity of Hevea brasiliensis: Quantitative Determination of Laticiferous Tissue. Rubb. Res. Inst. Malaya 23 (3): 193 203 
Goncalves, P. S., A. B. B. Cardinal., R. B. Dacosta., N. Bortoletto, and L. R. L. Gouvea. 2005. Genetic Variability and Selection for Laticiferous System Characters In Hevea brasiliensis. Genetic and Molecular Biology 28 (3) : 414-422.

Hadi, H. 2005. Sifat Ketahanan Beberapa Klon Karet Terhadap Penyakit Gugur Daun Corynespora. Jurnal Penelitian Karet 23(1): 36-47

Hadi, H., A. D. Wahyudi and K. Anwar. 2007. Performance of the Promoting Clones of Hevea Rubber Planted on Dry Climate Area. Proc. International Rubber Conference \& Exhibition 2007. Bali, 13 - 15 Juni. IRRDB-IRRI.: 379 383.

Mydin, K. K., T. Meenakumari., V. Thomas., T. Gireesh., C. Narayanan., T. R. Chandraseekar and J. Jacob. 2012. Multilocational Performance of RRII 400 Series Clones. Bulletin Rubber Board 30 (4) : $23-28$.

Novalina. 2009. Deteksi Marka Genetik yang Terpaut dengan Komponen Produksi Lateks pada Tanaman Karet (Hevea brasiliensis Muell Arg.) Melalui Pemetaan QTL. Disertasi. Program Pascasarjana. Institut Pertanian Bogor, Bogor.

Pawirosoemardjo, S. 1999. Epidomologi Dan Pengendalian Penyakit Gugur Daun Secara Terpadu. Laporan Penelitian. Proyek Penelitian Karet Sungei Putih, Medan.

Sayurandi dan Aidi-Daslin, 2012. Keragaan Pertumbuhan dan Produksi Klon Karet Harapan IRR Seri 200 pada Tahap pengujian. Prosiding Seminar dan Kongres Nasional Sumber Daya Genetik Pertanian. Medan, 12 - 14 Desember. FP USU.: 394-402
Setiono dan H. Hadi. 2006. Adaptabilitas dan Stabilitas Beberapa Klon Karet di Daerah Beriklim Kering. Pros. Lok. Nas. Budidaya Tanaman Karet. Medan, 4 - 6 September. Balai Penelitian Sungei Putih.: 62-70.

Siagian, N, I. Suhendry dan H. Munthe. 2005. Keragaan Pertumbuhan Beberapa Klon Anjuran Pada System Tanam Populasi Tinggi dan Berbagai Dosis Pupuk. Pros. Lok. Nas. Pemuliaan Tanaman Karet 2005. Medan 22-23 November. Pusat Penelitian Karet.: 227-250.

Sugiyanto, Y., H. Sihombing dan Darmandono. 1998. Pemetaan Agroklimat dan Tingkat Kesesuaian Lahan Perkebunan Karet. Pros. Lok. Pemuliaan Karet 1998 \& Diskusi Prospek Karet Alam Abad 21. Medan, 8 - 9 Desember. Pusat Penelitian Karet.: 201-222.

Suhendry, I. 2001. Pertumbuhan dan Produktivitas Tanaman Karet pada Beberapa Tipe Iklim. Jurnal Penelitian Karet 19(1-3): 18-31.

Thomanee, A., S. Chimsathit, and S.Sookmark. 1992. Progress Report on the 1974 Multilateral Exchange Clone Trials. ANRPC Report of the First Meeting of Plant Breeders. Hat Yai, Thailand, $16^{\text {th }}-17^{\text {th }}$ Januari. The Association of Natural Rubber Producing Countries.: 48-60

Thomas, W., A.Situmorang dan M.Lasminingsih. 2009. Pemilihan Klon Karet untuk Provinsi Lampung Berdasarkan Kondisi Agroklimat. Warta Perkaretan 28(1) : 19-27.

Vinod K. K., Suryakumar M., Chandrasekhar T. R., Nazeer M. A. 2010. Temporal Stability of Growth and Yield Among Hevea Genotypes Introduced to a Non-traditional Rubber Growing Region of Peninsular India. Ann. For. Res. 53(2): 107-115. 
Woelan, S., Aidi-Daslin, dan Sumarmadji. 2008. Keragaan Klon IRR Seri 200 Selama Tanaman Menghasilkan di Pengujian Plot Promosi. Pros. Lok. Nas. Agribisnis Karet 2008. Yogyakarta, 20 21 Agustus. Pusat Penelitian Karet.: 297-308.
Woelan, S. 2013. Peta Pautan Genetik dan Analisis QTL Tanaman Karet (Hevea brasiliensis Muell Arg.) Pada Populasi Hasil Persilangan RRIM 600 dan PN 1546 Sebagai Dasar Strategi Peningkatan Produksi Lateks. Disertasi. Program Pascasarjana. Universitas Sumatera Utara, Medan. 